\title{
ASSOCIATED FIELD SEMANTICS IN MODELING LESYA UKRAINKA'S IMAGE
}

\author{
Svitlana Bohdan \\ ORCID: 0000-0002-4831-2770 \\ bohdan.svitlana@eenu.edu.ua \\ Lesya Ukrainka Eastern European National University, Ukraine \\ Tetiana Tarasiuk \\ ORCID: 0000-0002-2428-447X \\ tarasiuk.tania@eenu.edu.ua \\ Lesya Ukrainka Eastern European National University, Ukraine
}

Received February 17, 2020; Revised April 6, 2020; Accepted May 2, 2020

\begin{abstract}
The article is focused on the study of the perception of Lesya Ukrainka, a famous Ukrainian writer, in contemporary Ukrainian society. The research is based on a free word association test held online with 200 respondents aged from 13 to 70 . As a result of applying quantitative analysis of the associates and semantic gestalt method the authors singled out productive semantic zones concerning each of the stimuli. These zones presented an anthroponymic triad of personality identification related to the author's names 'Larysa Kvitka', 'Larysa Kosach', and the pseudonym 'Lesya Ukrainka'. The nuclear zones in each associative field manifest a tendency for uniformity. They are related to her professional activities, her works, elements of inner and outer portrayal, as well as of evaluative spectrum. The respondents have shown predominantly high levels of knowledge about Lesya Ukrainka's personality, which is proven, in particular, by their reverse frequency reactions and peripheral character of zero reactions. A dominant positive evaluative spectrum of perception of Lesya Ukrainka, as well as productivity of individual associates of interpretational character, was also important.
\end{abstract}

Keywords: Lesya Ukrainka, associative field, word association test, semantic gestalt, semantic zones.

Богдан Світлана; Тарасюк Тетяна. Семантика асоціативного поля в моделюванні образу Лесі Українки.

Анотація. У статті на основі результатів вільного асоціативного експерименту, проведеного шляхом онлайн-опитування), досліджено особливості сприйняття Лесі Українки в сучасному українському соціумі, з'ясовано типологічні та індивідуальні реакції. На основі кількісного аналізу асоціатів та методу семантичного гештальту виокремлено продуктивні семантичні зони щодо кожного зі стимулів, які представляють антропонімійну тріаду іï особистісної ідентифікації - автоніми ЛАРИСА КВІТКА, ЛАРИСА КОСАЧ і псевдонім ЛЕСЯ УКРӒ̈НКА. Ядерні зони в кожному асоціативному полі виявили тенденцію до однотипності, вони стосуються іiї професійної діяльності, творів, елементів зовнішнього та внутрішнього портретування та оцінного спектру. Респонденти виявили в основному високий рівень

(C) Bohdan, Svitlana; Tarasiuk, Tetiana, 2020. This is an Open Access article distributed under the terms and conditions of the Creative Commons Attribution 4.0 International Licence (https://creativecommons.org/licenses/by/4.0/).

East European Journal of Psycholinguistics, 7(1), 28-47. https://doi.org/10.29038/eejpl.2020.7.1.boh 
обізнаності з персоналією Лесі Українки, про що засвідчують, зокрема, частотні обернені реакції та периферійність нульових. Важливий також виразно домінувальний позитивний оцінний спектр сприйняття Лесі Українки та продуктивність індивідуальних асоціатів інтерпретаційного характеру.

Ключові слова: Леся Украӥнка, асоціативне поле, асоціативний експеримент, семантичний гештальт, семантичні зони.

\section{Introduction}

The associative experiment, or word association test, is known to be one of the most frequently used methods in different spheres of research, primarily in contemporary sociology and psychology, and even more in psycholinguistics (Zalevskaja, 1978; Zalevskaja, 1990; Zalevskaja, 1994; Goroshko, 2001; Karaulov, 2000a; Terekhova, 2000; Terekhova, 2017; Shono, Ames, \& Stacy, 2016).

One of its types, the free associative experiment, is justly considered to be an optimal search tool for a personality's various differential mental features, as well as one of the most productive means of establishing dominant ethnic features (both autoand heterostereotypical) and modeling of typological images of individual representatives of certain ethnic groups. This is why frequency research above all, performed with this method, is oriented towards finding ethnic cultural peculiarities of language conscience (Kuzina, 2010; Sergieva, 2006; Hui, 2011; Namei, 2004; Séguin, 2015), different elements of a language map of the world (Zahorodnia, 2018), semantic conceptual fields (Nedashkivska, 2007; Pryschepa, Plechko, \& Svysiuk), professional and social stereotypes (Denysevych, 2010; Chekanova, 2008a; Chekanova, 2008b), and stereotypical female / male images (Borgoyakova \& Pokoyakova, 2012). Nevertheless, paradoxal as it may seem, contemporary linguopersonology (in particular, Ukrainian), which has the language personality as its object of study (his or her lexicon, thesaurus, and otivational features), almost overlooks the possibility of cognizing language personalities, primarily well-known, through associative experiments. And the most important fact is that there has been no research to focus on the study of the language conscience of Ukrainian respondents regarding their perceptions and modeling of wellknown writers, politicians, etc. The existing research studies personalities from other than Ukrainian society (Tsagolova, 2016). This motivated us to choose our research subject, i.e., the image of Lesya Ukrainka, which has been studied for the first time in the mentioned aspect.

\section{Methods}

In the study a method of free associative experiment is used in the search for typical (i.e., repeated, or collective - according to a different terminology) and individual features in the formation of an image of Lesya Ukrainka by contemporary speakers. A method of numerical analysis of data helped to define nuclear and peripheral zones within each field in particular, as well as in all three associative fields. 
Owing to the method of comparative analysis, both collective and individual reactions were found.

A method of semantic gestalt construction proved to be important for singling out dominant content zones in the modeling of differentiating features of Lesya Ukrainka's personality. This method was introduced by Karaulov and further developed in the works of Novikova and Kuzina (Novikova, 1988, Novikova, 2008; Kuzina, 2010), who shared Karaulov's view of most associative fields having a "special inner organization of their content", which reflects a pragmatic structure of every field. This pragmatic structure is called a "semantic gestalt" (Karaulov, 2000a, p. 194). This structure "restores a referent's model typical of a certain national culture. This model corresponds to a stimulus in reality surrounding a speaker of this language” (Novikova, 1988, p. 22-23). In other words, it is "built on the involvement of each reaction in a certain stereotypical quality of the referent in this language" (Goroshko, 2001). And this is why the formation the structure of the gestalt of a certain stimulus word is always related to the referent, what "stands behind this word in the speaker's conscience" (Goroshko, 2001). It is also important that a type (or variety) of a gestalt is formed by associates which are similar in content. "The semantic gestalt of an associative field becomes outlined" each time only with a "consistent and whole" analysis of an associative field, when the respondents' answers manifest certain characteristics of a stimulus which are grouped around frequency reactions-concepts "generally indicating typical features of a referent who stands in this culture behind the name of the field, i.e., behind the stimulus" (Novikova, 2008, p. 30). Therefore, a gestalt always "reproduces a model typical of a referent's national culture; the model corresponds to the stimulus in the reality surrounding the speaker of this language" (Novikova, 2008, p. 30).

Novikova believes that a gestalt type for speakers of the same language is a constant feature, i.e., it not only manifests national peculiarities, but also certain features of universality. At the same time, its content can differ, depending on: 1) time parameters of the associative field construction; and 2) characteristics of groups of the language speakers who take part in the experiment (Novikova, 1988, p. 27).

Semantic gestalt "characterizes the field as a unit of knowledge of the world, corresponding its structure with the structure of reality reflected in it. The gestalt usually consists of several zones (their number varies within $7 \pm 2$ ), which unite features (typical of this language conscience) of an object or concept which corresponds to the name of the field (= stimulus)". Strictly speaking, it is the semantic gestalt that creates preconditions for finding the most semantically significant segments, inherent in the whole associative-verbal network of every stimulus word, and enables constructing based on semantic classification of all typological reactions. Each zone, in Sergieva's opinion, is a characteristic of a certain significant feature, which collectively construct intensiveness of this stimulus, a generalized image of the perception of the world, and which stand behind this word (in our case - a well-known 
personality). In naming the zones, it is convenient to use pronominal markers which can convey the most general meanings ("Who", "What", "Which", "This", etc.) (Sergieva, 2006, p. 161). In our study the method of semantic gestalts is the basis for defining typical and semantically similar reactions in the modeling of the image of Lesya Ukrainka by contemporary speakers. The formation of a register of semantic gestalts regarding every stimulus word involved the procedure of finding stereotypical properties of a certain referent based on contentual similarity of elements of an associative field. To define nuclear and peripheral semantic zones we also partly used a method of a lexical semantic field (further - LSF), which involves, based upon paradigmatic relations between the elements of an associative field, the singling out of "words with a common hyperseme, i.e., the only (integral) meaning for the whole group" (Kocherhan, 2004, p. 305).

A free word association test (FWAT), regarding the search of defining features of language portrayal of Lesya Ukrainka, as well as of peculiarities of perception of her personality, was conducted by means of an anonymous electronic online survey which involved step-by-step responding to a stimulus (the survey's access mode: https://docs.google.com/forms/d/e/1FAIpQLSf419HwPIR_Ff41vOYmcrQhH0qz4J0kR ckxyyKwy9u_-shUWQ/alreadyresponded): the respondents could not see the whole register of offered nominations immediately. The latter made any prompt, even implicit, concerning Lesya Ukrainka's personality, impossible. Another specificity of our research was the register of stimuli words being represented with all three official proper names which serve as a means of anthroponymical identification of the wellknown Ukrainian writer, publicist and activist, namely: the authonames LARYSA KVITКА (ЛАРИСА КВІТКА - her legal name after her marrying Klyment Kvitka) and LARYSA КОSAСН (ЛАРИСА КОСАЧ - her maiden name), her pseudonym LESYA UKRAINKA (ЛЕСЯ УКРАÏHКA - the unique, individually created / madeup name - her penname, first used in 1884). These three names correspond to her personality and have been used regarding her in the language paradigm of the Ukrainian society and beyond (the marriage of Lesya Ukrainka and Klyment Kvitka was registered, as is known, on July 25, 1907). Still, not all of the mentioned names have uniform quantitative characteristics (first of all, regarding the frequency of their actualization in contemporary speech). The order of presenting (positional placement) of these proper names in the associative experiment was arranged with a clear motivation: from the least known - to well-known. The latter, in particular, largely enabled us to avoid the effect of "recognizability" of a real personality, on the one hand, - that is, created certain cognitive difficulties in the process of association. And on the other hand, the associative reaction itself was defined by, and correlated with, the level of being informed and cognitive abilities of the informer. As expected, the most productive in use and the widest-known name in the offered register of stimuluswords, i.e., LESYA UKRAINKA (ЛЕСЯ УКРАЇHКА), was at the end of the register. 
The latter provided the absence of even minimal projections towards her personality from the first two stimulus units.

The material of our research comprises the results of the FAE which involved a one-word / word combination/ sentence answer (though in reality some informers did not always comply with the request to choose just one reaction, in spite of its being lexically and syntactically heterogeneous). The experiment involved 200 respondents aged from 13 to 70; their occupation status being mostly teachers, school and college students, post-graduates, researchers; their residence being mostly Ukraine, and only a few respondents were from other countries (1 - Poland, 1 - France, 1 - the UK, 1 Israel); most respondents mentioned Ukrainian as their native language - 167; Russian - 25, Ukrainian and Russian - 4, Russian and Ukrainian - 3, Ukrainian and Polish - 1. We should remark that the experiment still continues in social networks, which will help us in the future to confirm or correct the discovered typological reactions and construct a complete associative image of Lesya Ukrainka.

In the answers we have consistently preserved the authors' spelling and graphic peculiarities (capitalization, italics, underlined parts, non-verbal markers); we have corrected only obvious typos (e.g., Салфо - Сапфо, Прометая - Прометея, мама Лесі Українки -мама Лесі Українки, еtс.).

\section{Results and Discussion}

As the result of the survey the associative fields have been created based on each word-stimulus. 13 different collective (repetitive) reactions and 38 individual reactions have been received on the first stimulus - LARYSA KVITKA (ЛАРИСА КВITКА), on the second stimulus - LARYSA KOSACH (ЛАРИСА КОСАЧ) - 8 and 42 respectively, on the third one - LESYA UKRAINKA (ЛЕСЯ УКРАÏHКA) 10 and 77.

The nominative field of the LARYSA KVITKA (ЛАРИСА КВІTКА) stimulus mainly comprises a set of one-word associates, at the same time the reactions represented by several words, word combinations and even several word combinations have been received (in this work every associate will be presented together with its quantitative parameters, the number of informants given in brackets).

The first thematic group of this stimulus associative field is created by the reactions which are directly or indirectly related to the personality of Lesya Ukrainka: Kosach / Kocaч 54 (Kosach / Косач 48 / 6 combined ones) (Kosach / Kocaч 43, KOSACH / KOCAЧ 2, Kosach-Kvitka / Косач-Квітка 1, Larysa Kosach / Лapuca Kocay 2, Larysa Kosach / Лapuca Kocay, Kvika-Osnovianenko / KвimкaОснов'яненко 1, Lesya Ukrainka / Леся Українка, Kosach / Косач 1, Larysa KvitkaLarysa Kosach / Лариса Квітка-Лариса Косач 1); Lesya Ukrainka / Леся Украӥнка 40 (Lesya Ukrainka / Леся Українка 31, Lesya Ukraynka / Леся Украънка 1, Larysa Kvitka / Лариса Квітка - LESYA Ukrainka / ЛЕСЯ Украӥнка 1, Lesya Ukrainka / Леся Українка, Kоsach / Косач 1, happy and smiling Lesya Ukrainka / щэаслива 
усміхнена Леся Украӥнка 1, Lesya Ukrainka with a flower in her hair / Леся Українка з заплетеною у волосся квіткою 1, as an association - a classical portrait of a manlike (unwomanly) Lesya Ukrainka / асоціативно - класичний портрет маскуліноподібної (нежіночної) Лесі Украӥнки 1, formality / офіціийність. Lesya Ukrainka / Леся Українка 1, Lеsуa Ukrainka / Леся Українка; a writer / письменниия 1, Lesya Ukrainka in an official mood / Леся Украӥнка в настрої офіuіозу 1, happy and smiling Lesya Ukrainka / щуаслива усміхнена Леся Украӥнка 1, Klyment / Климент, Lesya Ukrainka / Леся Украӥнка, disease / хвороба, Surami / Сурамі, in foreign parts / на чужині 1); poetess / noemeca - 13 (poetess / noетеса 7, poetess / noemeca 2), poetess / noemeca 7 , poetess / noemecca 1, perhaps poetess / напевно поетесса 1, Ukrainian роеtess / українська поетеса 1, brilliant poetess / геніальна поетеса 1, great роетеss / велика поетеса 1, Ukrainian wотап / украӥнка, poetess / noетеса 1); writer / письменниця 6 (writer / письменниця 5, Lesya Ukrainka / Леся Українка; writer / письменниия 1); wife / дружина 5 (wife / дружина 3, Klyment Kvitka' s wife / дружина Климента Квітки 1, Klyment's wife / дружина Климента 1), Klyment Kvitka / Климент Квітка 5 (Klym Kvitka / Клим Квітка 1, Klyment Kvitka / Климент Квітка 1, Климент 1), Klyment / Клемент 1, Klyment / Климент, Lesya Ukrainka / Леся Украӥнка, disease / хвороба, Surami / Сурамі, in foreign parts / на чужині 1); marriage / заміжжя 2 (marriage / заміжжя 1, Lesya Ukrainka marriage / заміжжя Лесі Украйнки 1, married / заміжня 1; Lеsya / Леся 4 (Lеsya / Леся 3 , married Lesya / одружена Леся 1; mother / мати mom / мамa 4 (mother / матu 1, Lesya's mom / мaмa Лeci 2, Lesya Ukrainka's тот / мама Лесі Українки1); Larysa Kvitka / Лариса Квітка 3 (repetition of the word-stimulus and the association itself: Larysa Kvitka - Larysa Kosach / Лариса Квітка-Лариса Косач 1, Larysa Kvitka - extraordinary woman / Лариса Квітка - непересічна жінка 1, Larysa Kvitka - LESYA UKRAINKA / Лариса Квітка - ЛЕСЯ Украӥнка 1); Ukrainka / Украӥнка 2 (Ukrainka / Украӥнка 1, Ukrainka / Украӥнка, poetess / noетеса 1); Ukraine / Украӥна 1; pseudonym / псевдонім 3; роеtеss / поетка 1; роетs / вірші 2, роеtry / поезія 1; Воуагуnia / Бояриня 1; hope against hope / без надї сподіватись 1; folk records / фольклорні записи 1; artist / митець 1; wотап / жінка 4 (wотап / жінка 2, wотап in prime / розквітла жінка 1, devoted шотап / віддана жінка 1); lessons of literature / уроки літератури 1.

Some of the associates from this group, combined by the common prop lexeme (at the level of syntagmatic associative relations), actualize certain evaluative responses of the respondents, explicating distinctive features of Lesya Ukrainka personality (various qualitative, relative or possessive characteristics, which mainly verbalize her somatic and vestal features) or express speakers' attitude to her via various attributive lexemes, for example: Klyment Kvitka's wife; married Lesya Ukrainka; Lesya Ukrainka in an official mood; happy and smiling Lesya Ukrainka; Lesya Ukrainka with a flower in her hair; a classical portrait of a manlike (unwomanly) Lesya Ukrainka; 
extraordinary woman; woman in prime; devoted woman; brilliant poetess; great poetess.

The second thematic group is formed by the associates that refer to other personalities (only sometimes simultaneous explication and Lesya Ukrainka reaction have been observed) and lexemes of the paradigmatic type related to them: Osnovianenko / Основ'яненко 9 (Osnovianenko / Основ'яненко 6, KvitkaOsnovianenko / Квітка-Основ'яненко 2, Larysa Kosach / Лариса Косач, KvitkaOsnovianenko / Квітка-Основ'яненко 1); Todos' Os'machka / Tодось Осьмачка 1; Tsisyk / Цісик 7 (tsisyk / цісик 3, Тsysyk / Цисик 1, Kvitka Tsisyk / Квітка Цісик 2; Kvitka / Квітка 1; Vakarchuk / Вакарчук 1; line for the song / рядок для пісні 1; song / пісня 1; music / музика 1.

The third group of associates is presented by the lexemes which may equally concern personalities named in the previous groups with different degree of probability: good surname / гарне прізвище 1; the only оnе / сдина 1; native / рідна 1; beautiful / гарна 3; beauty / красуня 1; romantic / романтично 1; girl / дівчина 1 ; aunt / mimка 2.

The motivation of the next group of associative reactions has definite individual expression: Taras oak / Tapac дуб 1; spring / весна 2; beginning / початок 2; to sow / сіяти 1; Flowers / Квітки 1; chamomile / ромашка 1; таrigold / чорнобривець 1; lily / лілія 1; serenity / спокій 1; hair / волосся 1; hippies, species of plants / xini, вид рослини 1. Zero associates are not numerous: none / ніякого 1, по associations / нема асоціацій 1; ? 2.

One of the reactions - pseudonym / псевдонім 1 - shows clear cognitive deviation of the respondent.

To study typological and individually peculiar features in Lesya Ukrainka portraying the best way is to utilize the semantic gestalts method (Karaulov, 2000b) and the method of lexical-semantic fields modeling that focus on the search of common semantic dominants within associative fields. The names of these zones have been formed based on the invariant semes of the key associates.

Several nuclear semantic zones may be singled out within the LARYSA KVITKA associative field:

1. Anthroponymic nominations of Lesya Ukrainka (official names - autonyms, pseudonyms, truncated versions of the name: Kosach, Lesya Ukrainka, Lesya).

2. Lesya Ukrainka professional occupation (poetess / поетка, роеtess / noemeca / noemeca, writer, artist).

3. Lesya Ukrainka as a married woman (this group comprises prop lexemes mainly: wife, marriage, married, Larysa Kvitka).

4. Lesya Ukrainka's husband (his full name and the most common versions of it, the surname: Klym, Klyment / Klement, Klyment Kvitka). 
5. Lesya Ukrainka as a representative of a particular ethnos or state (ethnonym - a Ukrainian, horonim - Ukraine).

6. Genres of literature in which Lesya Ukrainka fulfilled herself as an artist and her aphorisms (poems, poetry, folk records, hope against hope).

7. Different evaluative characteristics of Lesya Ukrainka (the only one, native, beautiful, beauty).

8. Names by gender (woman, girl, aunt).

This group of associates is created mainly due to established paradigmatic relations of the noun type (Larysa Kvitka - Lesya Ukrainka, Kosach, wife, a Ukrainian, Klyment Kvitka, poems, poetess, etc.), which form regular semantic zones of "WHO" and "WHAT".

The second group of near-nuclear zone semantic gestalts is connected to other personalities of the Ukrainian reality: Kvitka-Osnovianenko, a writer (Osnovianenko, Kvitka-Osnovianenko) and the American singer of Ukrainian origin Kvitka Tsisyk (Tsisyk, Kvitka, Kvitka Tsisyk). So, we can assume that associates song, music, line of the song also imply semantic relations with the personality of the singer Kvitka Tsisyk.

The periphery of semantic gestalts (mainly presented by single reactions) has been formed by individualized associates motivation of which is not always clear. First of all, it concerns the following associates:

1. The personalities of certain individuals of Ukrainian historic and modern arts and culture (similar to the previous thematic group): Todos' Os'machka, Vakarchuk (if the personality of the singer and composer Vakarchuk as an associate can be hypothetically motivated by the fact that there are some songs of Kvitka Tsisyk in Vakarchuk's repertoire, then Todos' Os'machka as an associate requires comments of the author and is individual).

2. Specific names - phytonyms, created on the basis of generic correlation (chamomile, lily, marigold).

3. Lesya Ukrainka's mother (the motivation of such reactions is double-natured - ambiguity / confusion or association by similarity (mother, Lesya's mom, Lesya Ukrainka's mom).

4. Anthroponymic status / type (pseudonym, good surname).

Semantically opaque reactions on this word-stimulus are also not numerous (they cannot be explained without knowing cognitive, situational prerequisites that have distinctly individualized features: Taras oak, spring, beginning, sow, serenity, hair, hippies, species of plants, romantic, though actualization of some of them may by commented on with different degree of possibility and assumption. It concerns, in particular, reactions spring and romantic. 
The associate pseudonym, which shows the respondent's lack of knowledge, belongs to communicative deviations.

Zero reaction is presented by verbal as well as by non-verbal signs: none, no associations, ?.

The nucleus of the nominative field of the word-stimulus LARYSA KOSACH has been formed, as predicted (basically - due to the dominating language of communication and the mother-tongue of the informants - the Ukrainian language) by the pseudonym Lesya Ukrainka and the surname Kvitka, which confirms the level of respondents' awareness and the ability to correctly identify her personality. The associate-pseudonym Lesya Ukrainka has been recorded as the most frequent (Lesya Ukrainka 54). This associate has different orthographic and graphic versions in some respondents' answers, like: Lesya ukrainka 1; Lesya ukrainka 2; Lesya Ukrainka 1; LESYA UKRAINKA 2; Lesya Ukraynka / Леся Украънка1 (which may be caused by some technical reasons). In their answers the respondents somewhat duplicate the name-stimulus: Larysa Kosach - Lesya Ukrainka 1. One answer was given in Russian - Lesya Ukrainka / Леся Украинка 1. Some reactions are presented by several prop lexemes: Lesya Ukrainka, writer 1. In one answer this associate is combined with two surnames of Lesya Ukrainka at the same time - Kvitka and Kosach, which confirms the high level of the respondents' awareness: Kvitka - Kosach or Lesya Ukrainka 1; Larysa Kvitka - Kosach, Lesya Ukrainka 1. The surname of the writer's husband quite predictably ranks second according to quantitative parameters in the associative field of this stimulus: Kvitka 25; kvitka 1; KVITKA!! 1; Kvytka 1.

The near-nucleus associative zone has been presented by the lexemes which form semantic zones: Lesya Ukrainka and her professional activity: writer (writer 5), Lesya Ukrainka and the state / ethnonymic status: Ukrainian / Украӥнка (Ukraininan / Українка 9, Ukraininans / українки 1 ) and Lesya Ukrainka and her name-patronymic - Petrivna (Petrivna 7).

It is worth mentioning that the associate referring to the professional status (being a writer) has two grammatical variants: both masculine and feminine (with clear quantitative prevalence of feminine names), sometimes in combination with the lexemes that actualize other semantic features, e.g.: writer (he-writer) / письменник 1; writer (she-writer) / письменниця 6; writer (she-writer) / письменниця, Olena Pchilka's daughter 1; poetess / поетка 1; poetess / noemeca 13; poetess / noemecca 1; Larysa Kosach - poetess 1 . Three respondents have mentioned that the stimulus Lesya Ukrainka is one of the means of her personalization: real name 2 and the poetess's real name 1 . The adverb associate officially 1 also refers to this feature.

The attributive features to the prop associative lexeme - Volyn and Ukrainian (Volyn writer 1; Ukrainian writer 1) express its ethnic characteristics and form peculiar synthesis of the two mentioned semantic zones - Lesya Ukrainka and her professional activity and Lesya Ukrainka and her ethnic differentiation. Semantics of the ethnic identification has been actualized by noun associates-onyms - names of 
places Volyn / Ukraine / Kyiv and ethnonyms Volyn woman (волинянка) / Ukrainian wотап (українка) (the most frequent among them are Volyn 4 and Volyn woman (волинянка) 1). Some of them explicate evaluative lexemes: great Ukraine 1, honor of Ukraine 1).

The reactions which actualize the personality of Lesya Ukrainka's mother also belong to the near-nucleus semantic zone: mother 2, mom 1, Lesya Ukrainka's mother 1, Lesya's mom 1, Lesya Ukrainka's mom 2. Although, as it has been mentioned concerning the stimulus Larysa Kvitka, we can hardly claim that for all the respondents equally these names have the semantics of correlation by family relations based on daughter - mother connection, instead of denoting the same person, especially taking into account the frequent aasociate-pseudonym of the mother, Olha KosachDrahomanova, - Olena Pchilka.

The periphery of this stimulus associative field (less than five associates) has been formed by the reactions with the gestalts semantically similar to the previous one: 1 . Lesya Ukrainka and her family (daughter 1, Lesya ukrainka's sister 1 (specific, comparing to the associates to the first stimulus). 2. Lesya Ukrainka gender characteristics (woman 1, intelligent woman 1, wise woman 1, redoubtable woman 1). 3. Lesya Ukrainka evaluative characteristics and her differential features (actualized by noun and adjective lexemes and word combinations-personifications: majestic 1 , amazing Larysa Kosach 1, treasurer / берегиня 1, creator 2, fighter 1, bее / бджілка 1, еducation / освіченість 1, talent 1, adamantine bloom / незламний иявіт 1, disease 1). 4. Lesya Ukrainka, different genres and her works (letters 1, poetry 1, poems 1). This group (comparing to the first associative field) is expanded by one associate nomination of the character from her work (Mavka 1) and the name of her work "Forest Song" - 1. 5. Toponymic (place) name of the Kosaches's family estate (Kolodiazhne 1). 5. Lesya Ukrainka identification before marriage (youth 1 , childhood 1).

The semantic gestalt Lesya Ukrainka and figurative stereotypes of the Soviet times, presented by the well-known periphrasis Prometheus' daughter 3, may be considered to be a specific type of this word-stimulus associative field.

Among peripheral associates we have singled out multi-componential reactions, which mainly constitute Lesya Ukrainka micro-portrayal with clear reflection of her personality differential features individual creation and emphasis on her professional and social status, on certain outer and inner features concretizing some vestal elements (noblewoman, poetess, proud Ukrainian 1; respectable woman wearing a long dress and a hat (Lesya Ukrainka in the photos of the late period) 1). The reaction Ukrainian national movement (1 (116)) identifies Larysa Kosach participation in the socialpolitical life of Ukraine of that time.

One more important semantic component of the associations of this word-stimulus is the temporal factor and correlation with the status married / single. In such a context the anthroponym Lesya Ukrainka shows semantic relations with the lexeme panna 
(miss) / панна, which is known to be a Ukrainian name-honoring of unmarried girls (panna (miss) Larysa Kosach 1). The descriptive phrase which implies the seme "time" - before writing the poem "Hope" (Lesya Ukrainka: before writing the poem "Hope") functions as a differentiation between the use of the two anthroponymic names - an official one (real) and a pseudonym (fictional). Similar semantics is displayed by another associate - officially recorded, documented individual, not artistic personality of Lesya Ukrainka 1), in which semantic markers common - artistic (personality) have been additionally presented, which creates double association. The associate Lesya Ukrainka, Kolodiazhne, poetess, strong personality, honor of Volyn 1 actualizes all main semantic features of the word-stimulus. And quite naturally the image of Larysa Kosach is expressed by the semantic correlation with the whole family of the Kosaches: the family nest of the Kosaches 1.

The periphery also includes the reactions marked by the situationality of associations, that is why decoding of their semantic relations with the word-stimulus is complicated. It concerns, in particular, the associate hutsulka 1, which must point at cognitive deviation, as well as a single reaction pseudonym.

A separate (not numerous) group has been formed by the associative reactions which do not have clear motivation and we have marked them as individual ones: pond 1, Victoria [personal name] 1, mow 1, pearl-hen 1, hair 1, Vika Porubliova 1.

One answer duplicates the previous one but to another word-stimulus given by the same respondent: the same 1.

The nominative field of the third stimulus - LESYA UKRAINKA - has been defined by several features: single zero reaction (I don't know 1) and the most numerous quantitative parameters of associates of different types 87 (compare LARYSA KVITKA 51, LARYSA KOSACH 50). It is probably caused by the fact that it is widely known in Ukrainian society and by high frequency of its actualization in language consciousness of Ukrainians (only few respondents from other countries participated in Free Associative Test).

The most productive reactions are the ones that have stable semantic relations at paradigmatic level, they present the semantic gestalt "WHO" and form its semantic zone: Lesya Ukrainka and her professional activity - literature / writing. The semantic field of such associates has been formed by the lexemes: poetess 17 (one time together with the word-stimulus: Lesya Ukrainka - poetess 1) / poetess 1, writer 9, poetess / поетка 2 and word-combinations with evaluative attributes: outstanding poetess 1, favourite poetess 1, Ukrainian writer 1, Ukrainian poetess 1, and also the name of school subject Ukrainian literature 1.

The thematic group Lesya Ukrainka - identification by gender, family ethnic status has been mainly actualized by noun lexemes-identifiers, that name her by certain differential features, often - in combination with evaluative attributes: daughter 1, woman 1 (strong woman 1, strong-willed Ukrainian woman 1), patriot 1, citizen of Lutsk / лучанка 1, Volynian / волинянка 1, Ukrainian / українка 1, authentic 
Ukrainian / справжня Українка 1, countrywoman / землячка 2, faтоus countrywoman 1 . Some individual associates have been created by several prop lexemes: Ukrainian poetess, spirited woman 1; outstanding poetess, famous Ukrainian 1; Larysa Kosach, writer, poetess 1.

A significant part of respondents focus on the fact that the name-stimulus is not a real name. Both direct and indirect associates-identifiers point out at that: pseudonym 2 and Larysa Kosach 5 / Larysa kosach 1, Kosach 1, Larysa Petrivna Kosach-Kvitka 1. One associate actualizes her autonym by her husband - Kvitka 1.

The semantic gestalt "WHAT" actualizes multiple semantic zones, which present thematic groups of names, formed on the basis of paradigmatic relations, peculiar for the previous two associative fields:

1. Different genres, in which Lesya Ukrainka realized herself (poems / поеми 1, poem 1, poems 3, Ukrainian poetry 1, letters 1), her works and characters (here clear variability of names and various orthography in the respondents' answers are especially noticeable), among the most frequent ones are "Forest Song" and "Contraspemspero": "Forest Song" and "Cherries / Вишеньки" (in such order) 1 / "Forest Song" 2 / Forest song 10 / forest song 1, Lesya Ukrainka Forest song 1 / Dramo-Feerie "Forest Song" (Драмо-фесрія «Лісова пісня») 1 / Drama-Feerie “Forest Song”( Драма-феєрія «Лісова пісня» ) 1; ContraSpemSpero! 1 / Contra spem spero 2 / Contra spem sperum (mistakes in the answers have not been corrected here and further on) 1, Hope against hоре (Без надіï сподіваюсь) 2 / Норе аgаinst hope (Без надіï сподіватися) 1 / Still hope against hоре (Без надіï таки сподіваюсь) 1; single reactions are presented by names of such works as Bygone Spring / Давня весна 1, "Kasandra" 1, On the Field of Blood / На полі крові 1, The Obsessed / Одержима 1, Норе / Надія 1, by the first line of the poem (Dream, don't betray, I have been in sorrow for so long / Mpic, не зрадь, я так довго до тебе тужила 1, As a child I used to / Як дитиною бувало 1) or by quotation / quotations from them (sometimes - not accurate): was lying sick and lonely / лежала хвора й самотна 1, “Ноw painful?” they asked / Як болить мене питали 1, "I was laughing not to сry" / «щоб не плакать, я сміялась»; "who told you I am weak?” / «хто вам сказав, щчо я слабка?» 1.

We have also recorded the reactions with some contaminations-errors of the author's text. The thematic status of some associates of this semantic zone has ambiguous expression. We may assume that reactions zoviili lysty (faded letters) / зов 'їлі листи 1 and zoviila troyanda (faded rose) / зов'яла троянда 1 probably refer to the work "Your letters always smell of faded roses" («Твої листи завжди пахнуть зов'ялими»).

Among the names of characters explication of the main character of "Forest Song” is rather frequent (Mavka 9 / MAVKA 1/ mavka 1).

2. Nominations of certain concrete objects, directly related to her commemoration (streets, monuments, educational institutions, money named after her), sometimes associates of the combined type have been actualized: avenue 1, monument 
1, Lesya Ukrainka Eastern European University 1, Volyn university 1, hryvnia 1, 200 hryvnias 3, 200, theatre, literature 1.

3. Associates that characterize Lesya Ukrainka physical condition and concern her health, to be more precise, her being unhealthy (which belong to the frequent ones in stereotypical portrayal of her image in educational environment and mass media): disease 1, tuberculosis 1.

The periphery zone of this associative field has been created by the semantic gestalt "WHAT / ЯKA". These are mainly adjective lexemes, which portray her by distinctive features (inner and outer) or are stereotypical evaluative characteristics: plait 2, tired 1, strong-willed 1, famous 1, genius 4, brilliant Lesya Ukrainka 1, wise and strong personality 1, glorious daughter of the Ukrainian nation 1.

Equally frequent reactions of this semantic zone have been verbalized by noun lexemes, attributive word-combinations: perseverance 1, courage 1, invincibility 1, emancipation 1, fight for women's rights 1 and by semantically relevant wordcombinations fragility and courage 1, boldness and completeness 1, art and intelligence 1 , unreachable height and pain 1.

The semantic gestal “THIS / ЦЕ” actualizes, first of all, all figurative, mainly periphrastic, names, explicated by both one-component and multi-component language units. Among them we have singled out stereotypical ones (Obsessed / Одержима 2, Ukrainian Sappho 1, daughter of Volyn region / донька Волинського краю 1, PROMETHEUS' DAUGHTER !!!! 1 / Prometheus' daughter 1, Prometheus' Daughter 1 , the only man in the Ukrainian literature 1, "almost the only man in modern Council Ukraine" 1, our Lesya 1) and individually outlined names (flower of Ukraine 1, voice of Ukraine 1, Ukrainian soul 1, soul of nation 1, heart of nation 1, beacon of nation 1 , pride 1 , pride of nation 1 , our pride 1 , national pride 1 , symbol 1, enthusiasm 1, fortitude 1, hope and soul 1, ever-living 1, Woman of the Sun 1).

A significant part of this semantic zone has been formed by the names of states and cities, related to her image (Volyn - 5, Kolodiazhne 5 / village of Kolodiazhne 1, Lutsk 2, Ukraine 1 and Georgia 1).

The associates to the word-stimulus LESYA UKRAINKA, which combine several semantic zones, are not numerous: Forest song, disease 1, poetess / поетка, translator, example 1, Volyn; Mavka 1. One answer is presented by a mini-description of the most common photo of the writer: a page in the Ukrainian literature textbook, in which there is a portrait of Lesya which she didn't like 1.

Individual reactions explicate emotional feelings and attitude to her personality: Lesya Ukrainka inspires 1, respect 1.

The comparative analysis of all the three associative fields has made it possible to single out collective nuclear reactions, among which the most frequent ones are autonyms Larysa Kvitka, Larysa Kosach and the pseudonym Lesya Ukrainka (see Table 1). 


\section{Table 1}

Nuclear Associative Markers of Lesya Ukrainka Image Modelling

\begin{tabular}{lccccc}
\hline & $\begin{array}{c}\text { N of reactions } \\
\text { (collective / } \\
\text { individual) }\end{array}$ & $\begin{array}{c}\text { Professional } \\
\text { activity }\end{array}$ & $\begin{array}{c}\text { Genres, } \\
\text { works }\end{array}$ & Locus & $\begin{array}{c}\text { Evaluative } \\
\text { characteristics }\end{array}$ \\
\hline $\begin{array}{l}\text { Larysa } \\
\text { Kvitka }\end{array}$ & $13 / 38$ & 21 & 4 & 0 & 8 \\
$\begin{array}{l}\text { Larysa } \\
\text { Kosach }\end{array}$ & $8 / 42$ & 26 & 2 & 9 & 12 \\
$\begin{array}{l}\text { Lesya } \\
\text { Ukrainka }\end{array}$ & $10 / 77$ & 33 & 24 & 18 & 25 \\
\hline
\end{tabular}

The defined semantic zones illustrate frequent use of reverse reactions: LARYSA KVITKA - Lesya Ukrainka, Larysa Kosach, Kosach-Kvitka, Kosach, LARYSA KOSACH - Lesya Ukrainka, Larysa Kvitka-Kosach, LESYA UKRAINKA - Larysa Kosach, Larysa Petrivna Kosach-Kvitka (see quantitative parameters of their typological representation in Table 2).

\section{Table 2}

Reverse Associations

\begin{tabular}{lccc}
\hline & Larysa Kvitka & Larysa Kosach & Lesya Ukrainka \\
\hline Larysa Kvitka & 3 & 27 & 0 \\
$\begin{array}{l}\text { Larysa } \\
\text { Kosach }\end{array}$ & 51 (just Kosach) & 1 & 2 \\
$\begin{array}{l}\text { Lesya } \\
\text { Ukrainka }\end{array}$ & 37 & 68 & 1 \\
\hline
\end{tabular}

The cases of Lesya Ukrainka image depersonalization have been noticed only for the stimulus Larysa Kvitka (see Table 3).

Table 3

Personal Identification with Other People

\begin{tabular}{lccc}
\hline & Larysa Kvitka & Larysa Kosach & Lesya Ukrainka \\
\hline Osnovianenko & 9 & 0 & 0 \\
Todos' & 1 & 0 & 0 \\
Os’machka & 7 & 0 & 0 \\
Tsisyk & 1 & 0 & 0 \\
Vakarchuk & & 0 & \\
\hline
\end{tabular}




\section{Conclusions}

Every field associative with a suggested stimulus word is constructed of units which are structurally and semantically heterogeneous, i.e., words, word combinations, phraselological units, free expressions. Among the most common are one-word noun reactions. In addition, word combinations and associates, formed by paradigmatic and syntagmatic connections with stimuli words can be considered productive, and complex word combinations formed by combining several basic words-reactions, as well as phrasal expressions, are considered non-productive. Silence-type reactions constitute the periphery.

The conducted research gives us grounds to draw a conclusion about most respondents as being well-informed concerning the author's names (real nominationsidentificators) of Lesya Ukrainka. The stimulus word LARYSA KVITKA (ЛАРИСА KBITKA) created the most cognitive difficulty, which caused the emergence of associates of other thematic groups with the basic lexeme kvitka / квітка (in particular, of the writer Kvitka-Osnovianenko, the singer Kvitka Tsicyk, etc.) Lack of knowledge of Lesya Ukrainka's real names, as well as of associating them both with her personality, has caused reactions which explicated images of other well-known Ukrainian personalities.

The appearance of associates which actualized the writer's mother's penname cannot be interpreted unambiguously: they can be, to an equal degree, both a sign of an associative deviation as a result of the respondents' insufficient knowledge, and of creation of habitual paradigmatic family-type connections on a semantic level, i.e.: daughter-mother.

It is worth remarking that associative fields of all three stimuli units have a minimal number of zero reactions. We have registered only one such associate with the stimulus LESYA UKRAINKA / ЛЕСЯ УКРАÏHКA, which confirms a high level of the respondents' knowledge, as well as their high cognitive abilities.

With the third stimulus, we have registered the largest number of different periphrastic nominations and evaluative lexemes as associates which explicate a pronounced emotional expressive perception of Lesya Ukrainka's personality in the contemporary society.

The main semantic zones have been actualized with all the stimuli words, namely: Lesya Ukrainka and her professional activities, her works and genres, distinctive features of her outward (seldomly) and inward portrayal (frequently), her ethnonymy status, gender characteristics, toponymy (cities and countries connected with her). The most productive were associates which belong to the generalized semantic zones: "WHO", "WHAT", and "THIS". We have also discovered special semantic zones with every stimulus, namely, with the first stimulus, LARYSA KVITKA / ЛАРИСA KBITKA: Lesya Ukrainka and her status as a married woman; her husband; with the stimulus LARYSA КОSAСН / ЛАРИСА КОСАЧ: her patronymic Petrivna; and with 
LESYA UKRAINKA: specific objects, realia, in particular, oney, educational establishments.

It is important that, in contrast to some actively used stereotypes about the image of Lesya Ukrainka (in particular, in mass media, and in the educational environment, first and foremost in schools), as "a sick, but strong/courageous woman", "a woman with a masculine character" (the latter being a transformation of the well-known quotation by Ivan Franko about her being "probably the only man in the whole newtime united Ukraine”), the assotiative perception and portrayal of her image in the contemporary society has shown, first and uppermost, a clear tendency for individually outlined positive modeling (as opposed to the frequency of a usual evaluation specter i.e., neutral and periphrastic nominations), which partly reflects the destruction of common standards. The latter is probably caused by, first, a sufficiently high level of a language conscience and knowledge of the respondents, which contributed to the formation of a definitely positive and emotionally coloured image of Lesya Ukrainka. The availability of identical or similar semantic zones in associative fields confirms a stereotypical character of the contemporary speakers' perception of her personality, independent of their age, professional and gender characteristics. The registered individual associates in all the three fields have clear shades of meanings and emotions.

It is also important to mention graphical markers in some respondents' answers, mostly represented by punctuation marks and different fonts, which contribute to specify the evaluative character of perception of Lesya Ukrainka's personality.

\section{References}

Боргоякова Т. Г., Покоякова К. А. Лексикографическая и психолингвистическая репрезентация образа женщины в разных лингвокультурах. Вестник Новосибирского государственного университета. Серия: Лингвистика и межкультурная коммуникация. 2012. № 10(2). С. $45-50$.

Горошко Е. И. Интегративная модель свободного ассоциативного эксперимента. Харьков; Москва : РА-Каравелла, 2001. URL: http://www.textology.ru/razdel.aspx?ID=38

Денисевич О. Вільний асоціативний експеримент як засіб дослідження соціального портрету. Волинь-Житомирщина. Історико-філологічний збірник з регіональних проблем. 2010. № 22(II). C. 334-340.

Загородня О. Асоціативні поля суспільно-політичної лексики в мовній картині світу українців (комп'ютерне опрацювання результатів психолінгвістичного експерименту) : автореф. дис. ... канд. філол. наук : 10.02.21. Київ, 2018. 20 с.

Залевская А. А. Вопросы организации лексикона человека в лингвистических и психологических исследованиях. Калинин, 1978. 88 с.

Залевская А. А. Слово в лексиконе человека: психолингвистическое исследование. Воронеж : Изд-во Воронежского университета, 1990. 204 с.

Залевская А. А. Функциональная основа разграничения парадигматических и синтагматических связей при анализе материалов ассоциативных экспериментов.

Структурно-семантические исследования русского язика. Воронеж : Изд-во ВГУ, 1994. C. 5-13. 
Караулов Ю. Н. Ассоциативный анализ: новый подход к интерпретации художественного текста. Вопросы психолингвистики. 2015. № 3(25). С. 14-35.

Караулов Ю. Н. Показатели национального менталитета в ассоциативно-вербальной сети. Языковое сознание и образ мира / отв. ред. Н. В. Уфимцева. Москва: Ин-т языкознания PAH, 2000. С. 191-206.

Караулов Ю. Н. Семантический гештальт ассоциативного поля и образы сознания. Языковое сознание: содержание и функционирование: тез. док. ХІІІ Международного симпозиума по психолингвистике и теории коммуникации (Москва, 1-3 июня 2000 г.) / отв. ред.

Е. Ф. Тарасов. Москва, 2000. С. 107-108.

Кочерган М. Л. Лексико-семантична система. Украӥнська мова: енциклопедія / за ред. В. М. Русанівського, О. О. Тараненка. Київ, 2004. С. 305-306.

Кузина О. А. Семантический гештальт как способ выявления этнокультурной специфіки язикового сознания (на примере семантического гештальта микрополя «Бюро путешествий»). Филология и человек. 2010. № 2. С. 46-55.

Недашківська, Т. Є. Асоціативне семантичне поле концептів професійність, служіння, мета, повноваження, завдання у професійній свідомості державних службовців. Вісник Національної академї державного управління. 2007. № 4. С. 65-73.

Новикова А. М. «Семантический гештальт» в структуре ассоциативного поля. Москва, 1988.

Новикова А. М. Использование в рамках ассоциативного поля функциональной структуры «язык-действительность» при обучении переводу художественных текстов. Русистика. 2008. № 2. С. 29-34.

Прищепа, О. П., Плечко, А. А., Свисюк, О. В. Особливості вербалізації концепту Україна в мовомисленні сучасної української молоді. URL: http://ir.znau.edu.ua/bitstream/123456789/9593/1/NVNUBiP_18_292_109-116.pdf.

Покоякова К. А. Образ мужчины в языковом сознании русских и американцев. Филологические науки. Вопросы теории и практики. 2013. № 7(2). С. 147-149.

Сергиева Н. С. Семантический гештальт и ядро языкового сознания русских. Вестник ЮжноУральского государственного университета. Серия: Социально-гуманитарнье науки. 2006. № 2(57). С. 160-165.

Терехова Д. І. Типологія вербальних асоціацій у вільному асоціативному експерименті. Наукові записки. Серія: Філологічні науки (Мовознавство). 2000. № 26, С. 236-246.

Терехова Д. І. Психолінгвістичний аналіз асоціативних полів слова-стимулу друг за даними спрямованих асоціативних експериментів. Вісник Київського національного лінгвістичного університету. Серія Філологія. 2017. № 20(2). С. 85-91.

Цаголова В. А. Моделирование образа политика Ангелы Меркель на материале ассоциативного эксперимента. Актуальные проблемы филологии и педагогической лингвистики. 2016. № 3(23). С. 65-70.

Чеканова С. А. Семантическое поле «профессия» в картине мира носителей языка (на материале русского и английского языков) : автореф. дисс. ... канд. филол. наук : 10.02.19. Москва, 2008. 24 с.

Чеканова С. А. Сравнительный анализ ассоциативных полей слова-стимула «экономист» (современные русские и англичане). Филологические науки в МГИМО. 2008. № 33. C. 111-118.

Hui, L. (2011). An Investigation into the L2 Mental Lexicon of Chinese English Learners by Means of Word Association. Chinese Journal of Applied Linguistics, 34(1). https://doi.org/10.1515/cjal.2011.005 
Namei, S. (2004). Bilingual lexical development: A Persian-Swedish word association study. International Journal of Applied Linguistics, 14 (3), 363-388. https://doi.org/10.1111/j.14734192.2004.00070.x

Séguin, M. (2015). Exploration of the relationship between word-association and learners’ lexical development with a focus on American L1 and Croatian L2 speakers. Explorations in English Language and Linguistics, 3(2), 80-101. https://doi.org/10.1515/exell-2017-0003

Shono, Y., Ames, S., Stacy, A. (2016). Evaluation of Internal Validity Using Modern Test Theory: Application to Word Association. Psychological Assessment, 28(2), 194-204. https://doi.org/10.1037/pas0000175

\section{References (translated and transliterated)}

Borgoyakova, T. G., \& Pokoyakova, K. A. (2012). Lexicographic and Psycholinguistic Representation of a Woman in Different Cultures. Vestnik Novosibirsk State University. Series: Linguistics and Intercultural Communication, 10(2), 45-50.

Goroshko, E. I. (2001). Integrativnaja model' svobodnogo associativnogo eksperimenta. Kharkiv; Moscow: RA - Karavella. Retrieved from http://www.textology.ru/razdel.aspx?ID=38

Denysevych, O. (2010). Vilnyi asotsiatyvnyi eksperyment yak zasib doslidzhennia sotsialnoho portretu [The Free Associative Experiment as a Mean of Researching the Social Portrait]. Volyn-Zhytomyrshchyna. Istoryko-filolohichnyi zbirnyk z rehionalnykh problem - VolynZhytomyrshchyna. Historical-Philological Digest on Regional Problems, 22(2), 334-340.

Zahorodnia, O. F. (2018). Asotsiatyvni polia suspilno-politychnoi leksyky v movnii kartyni svitu ukraintsiv (kompiuterne opratsiuvannia rezultativ psykholinhvistychnoho eksperymentu) [Associative fields of social and political lexis in the Ukrainian language world view (computer processing of the psycholinguistic experiment results)]. Unpublished Ph.D. dissertation. Kyiv.

Zalevskaja, A. A. (1978). Voprosy organizacii leksikona cheloveka v lingvisticheskih i psihologicheskih issledovanijah [The Issues of the Individual's Lexicon Structure in the Linguistic and Psychological Research]. Kalinin.

Zalevskaja, A. A. (1990). Slovo v leksikone cheloveka: psiholingviticheskoe issle-dovanie [A Word in the Lexicon of a Person: Psycholinguistic Study]. Voronezh: Voronezh University.

Zalevskaja, A. A. (1994). Funkcional'naja osnova razgranichenija paradigmaticheskih i sintagmaticheskih svjazej pri analize materialov associativnyh jeksperimentov [The functional basis of the distinction between paradigmatic and syntagmatic relationships in the analysis of the materials of associative experiments]. Strukturno-semanticheskie issledovanija russkogo jazyka - Structural and semantic studies of the Russian language, (pp. 5-13). Voronezh.

Karaulov, Yu. (2015). Associativnyj analiz: novyj podhod k interpretacii hudozhestvennogo teksta [Association analysis: the new approach to the literary text interpretation]. Voprosy Psiholingvistiki - Journal of Psycholinguistics, 25, 14-35.

Karaulov, Yu. N. (2000a). Pokazateli nacional'nogo mentaliteta v associativno-verbal'noj seti [Indicators of national mentality in associative-verbal network]. In: Jazykovoe soznanie i obraz mira - Linguistic Consciousness and World Image (pp. 191-206). N. V. Ufimceva (Ed.). Moscow: Institute of Linguistics of the Russian academy of Sciences.

Karaulov, Yu. N. (2000b). Semanticheskij geshtal't associativnogo polja i obrazy soznanija [Semantic gestalt of the associative field and images of consciousness]. In: Jazykovoe soznanie: soderzhanie i funkcionirovanie. XIII Mezhdunarodnyj simpozium po psiholingvistike i teorii kommunikacii. Tezisy dokladov (g. Moskva, 1-3 ijunja 2000 g.) - Linguistic Consciousness: Content and Functioning. XIII International Symposium on Psycholinguistics and Theory of 
Communication. Abstracts (Moscow, June 1-3th, 2000) (pp. 107-108). E. F. Tarasov (Ed.). Moscow.

Kocherhan, M. L. (2004). Leksyko-semantychna systema [Lexical-Semantic System]. Ukrainska mova: entsyklopediia - Ukrainian Language: Encyclopedia, (pp. 305-306), V. M. Rusanivskyi, \& O. O. Taranenko (Eds.). Kyiv.

Kuzina, O. A. (2010). Semanticheskij geshtal't kak sposob vyjavlenija jetnokul'turnoj specifiki jazykovogo soznanija (na primere semanticheskogo geshtal'ta mikropolja «Bjuro puteshestvij») [Semantic gestalt as a means to identify the ethnocultural specifics of linguistic consciousness (case study of the semantic gestalt of the micro-field “Travel Bureau”)]. Filologija i chelovekPhilology \& Human, 2, 46-55.

Nedashkivska, T. Ye. (2007). Asotsiatyvne semantychne pole kontseptiv profesiinist, sluzhinnia, meta, povnovazhennia, zavdannia u profesiinii svidomosti derzhavnykh sluzhbovtsiv [The Associative Semantic Field of the Concepts of professionalism, service, goal, powers, responsibilities in the Professional Consciousness of the Civil Servants]. Visnyk Natsionalnoi akademii derzhavnoho upravlinnia - Bulletin of the National Academy of Public Administration, 4, 65-73.

Novikova, A. M. (1988). "Semanticheskij geshtal't" v strukture associativnogo polja - "Semantic Gestalt” in an associative field structure. Moscow.

Novikova, A. M. (2008). Use within the framework of an associative field of functional structure "language - reality" with the instruction in transfer of the artistic texts. Rusistika, 2, 29-34.

Pryschepa, O. P., Plechko, A. A., \& Svysiuk, O. V. Osoblyvosti verbalizatsii kontseptu Ukraina v movomyslenni suchasnoi ukrainskoi molodi [The Verbalization Peculiarities of the Concept Ukraine in the Mentality of Modern Ukrainian Youth]. Retrieved from http://ir.znau.edu.ua/bitstream/123456789/9593/1/NVNUBiP_18_292_109-116.pdf

Pokoyakova, K. A. (2013). Image of man in russians and americans language consciousness. Philological Sciences. Issues of Theory and Practice, 7(2), 147-149.

Sergieva, N. S. (2006). Semanticheskij geshtal't i jadro jazykovogo soznanija russkih [Semantic Gestalt and the linguistic consciousness core of the Russians]. Vestnik Juzhno-Ural'skogo gosudarstvennogo universiteta. Serija: Social'no-gumanitarnye nauki - Bulletin of South Ural State University. Series “Humanities and Social Sciences”, 2 (57), 160-165.

Terekhova, D. I. (2000). Typolohiia verbalnych asotsiatsii u vilnomu asotsiatyvnomu eksperymenti [Typology of the Verbal Associations in a Free Associative Experiment]. Naukovi zapysky. Seriia : Filolohichni nauky (Movoznavstvo) - Scientific Notes. Series: Philological Sciences (Linguistics), 26, 236-246.

Terekhova, D. I. (2017) Psykholinhvistychnyi analiz asotsiatyvnykh poliv slova-stymulu druh za danymy spriamovanykh asotsiatyvnykh eksperymentiv [Psycholinguistic Analysis of Associative Fields of Word-Stimulus Друг (Friend) According to the Data of Directed Associative Experiments]. Visnyk Kyivskoho natsionalnoho linhvistychnoho universytetu. Seriia Filolohiia - Visnyk of Kyiv National Linguistic University. Series Philology, 20(2), 85-91.

Tsagolova, V. (2016). Modeling of the Image of Politician Angela Merkel on the Material of Associative Experiment. Current Issues in Philology and Pedagogical Linguistics, (23), 65-70.

Chekanova, S. A. (2008a). Semanticheskoe pole «professija» v kartine mira nositelej jazyka (na materiale russkogo i anglijskogo jazykov) [Semantic field of PROFESSION in the native speakers' picture of the world]. PhD Thesis Abstract. Moscow.

Chekanova, S. A. (2008b). Sravnitel'nyj analiz associativnyh polej slova-stimula «jekonomist» (sovremennye russkie i anglichane) [Comparative analysis of the associative fields of the word- 
stimulus “economist” (modern Russians and Englishmen)]. Filologicheskie Nauki v MGIMO Philological Sciences, 33, 111-118.

Hui, L. (2011). An Investigation into the L2 Mental Lexicon of Chinese English Learners by Means of Word Association. Chinese Journal of Applied Linguistics, 34(1). https://doi.org/10.1515/cjal.2011.005

Namei, S. (2004). Bilingual lexical development: A Persian-Swedish word association study. International Journal of Applied Linguistics, 14 (3), 363-388. https://doi.org/10.1111/j.14734192.2004.00070.x

Séguin, M. (2015). Exploration of the relationship between word-association and learners' lexical development with a focus on American L1 and Croatian L2 speakers. Explorations in English Language and Linguistics, 3(2), 80-101. https://doi.org/10.1515/exell-2017-0003

Shono, Y., Ames, S., Stacy, A. (2016). Evaluation of Internal Validity Using Modern Test Theory: Application to Word Association. Psychological Assessment, 28(2), 194-204. https://doi.org/10.1037/pas0000175 